\title{
The Role of Higher Education Institutions in Economic Development: Atlantic Canada as a Case Study
}

Wade Locke ${ }^{1}$

\begin{abstract}
This paper describes and assesses the contribution to economic development of higher education institutions in Atlantic Canada, the most economically depressed region of Canada. It provides a brief overview of the economic circumstances of the region and describes the relevant governance structure that influence the effectiveness of the higher education institutions in facilitating and enhancing economic development within Atlantic Canada. The avenues through which these institutions affect development within the region are considered. In addition, five examples of successes are profiled that may be helpful to other jurisdictions that are concerned with tapping into the intellectual capital at their institutions to enhance the economic development of their regions. Finally, this paper offers suggestions about how the situation in Atlantic Canada might be improved further.
\end{abstract}

Keywords: higher education institutions; economic development; Atlantic Canada; regional engagement; competitiveness.

\section{O Papel das Instituições de Educação Superior no Desenvolvimento Econômico: Um Estudo de Caso de Atlantic Canada}

Resumo: Este artigo descreve e avalia a contribuição das instituições de educação superior para o desenvolvimento econômico de Atlantic Canada, a região economicamente mais deprimida do Canadá. Ele fornece um breve panorama da situação econômica da região e descreve a relevante estrutura de governança que influencia a efetividade das instituições de educação superior em facilitar e acen-

1 The author can be reached at the Department of Economics, Memorial University of Newfoundland, St. John's, NL, Canada, A1C 5S7. E-mail address: wlocke@mun.ca. The author wishes to thank Cyril Farrell for helpful suggestions. Errors and omissions are the sole responsibility of the author. 
tuar o desenvolvimento econômico dentro de Atlantic Canada. As possibilidades através das quais estas instituições afetam o desenvolvimento dentro da região são consideradas. Além disso, cinco exemplos de sucesso são descritos de modo que podem ser úteis a outras jurisdições que estejam preocupadas em fazer uso do capital intelectual de suas instituições para acentuar o desenvolvimento econômico de suas regiões. Por fim, este artigo oferece sugestões acerca de como a situação em Atlantic Canada pode ser melhorada no futuro.

Palavras-chave: instituições de educação superior; desenvolvimento econômico; Atlantic Canada; engajamento regional; competitividade.

JEL: I20, R10

\section{Introduction}

In today's economy, local businesses and regions are exposed to international competition from all parts of the globe at an ever accelerating rate. Moreover, the nature of this competitive threat is increasingly becoming more knowledge intensive. Consequently, a region's competitive advantage is defined by its ability to generate and utilize knowledge that is both locally-relevant and contributes to innovation so as to both increase the productivity and improve the cost competitiveness of the region in an international context. In this environment higher education institutions have an enhanced potential to contribute to the economic development of the region in which they are located. The importance of this potential economic development contribution is magnified if the institution is located in a peripheral region of a country. Typically, in these regions, the private sector that may not be developed sufficiently or have the requisite critical mass to fully exploit the opportunities created by increased competition. Moreover, they may not be well positioned to deal effectively with the threats to their existence resulting from an evolving and expanding knowledge-based international competition.

Given this context, this paper provides an overview of the economic development role that higher education institution have played and can continue to play in Atlantic Canada, the most economically depressed region of Canada. This includes a consideration of how higher education institutions can and do impact upon economic development within Atlantic Canada. A description of the state of economic development within Atlantic Canada is also provided. The paper concludes with a brief discussion of some of the successes that have been achieved within Atlantic Canada that may serve as examples for other jurisdictions. 


\section{Canada - A Brief Introduction}

Canada, encompassing five time zones, is a large country geographically with a dispersed population. As of October 1, 2007, there were slightly more than 33 million people in Canada spread over nine million square kilometers for a density of 3.7 people per square kilometer.

The legislative structure within Canada consists of two levels of independent, non-hierarchal governments that are recognized explicitly in and guaranteed under the Constitution of Canada - the federal government (Government of Canada) and the 10 provincial governments. In addition, there are three territorial governments and thousands of municipal governments, operating within Canada. ${ }^{2}$

Education is a provincial responsibility under the Canadian Constitution, but the federal government does transfer money indirectly to fund postsecondary education. As such, there is no federal or national department of education that would be found in most other countries. Instead, the Council of Ministers of Education, Canada, composed of Ministers of Education from the 10 provinces and three territories, acts as the national voice for education in Canada and represents Canada's position internationally with respect to post-secondary educational issues.

\section{Atlantic Canada by the Numbers}

The four most eastern provinces of Canada, consisting of Newfoundland and Labrador (506,000 people), Prince Edward Island (139,000 people), Nova Scotia (934,00o people) and New Brunswick (750,00o people), make up what is commonly referred to as Atlantic Canada. While these four provinces are frequently referred to as the region of Atlantic Canada, it is important to understand that Atlantic Canada is a loose association of adjacent provinces that have similar histories, comparable cultures and, at times, common interests. That is, Atlantic Canada is a concept, not a constitution entity. ${ }^{3}$ Although it is not really a separate region ${ }^{4}$, Canadians understands what is encompassed by the term. Moreover, it is a conception that works reasonably well within the Canadian context; especially in terms of planning federal programs on a

\footnotetext{
2 The three territorial governments (the Yukon Territory, the Northwest Territories and Nunavut) come under the constitutional authority of the federal government, while municipal governments are creations of the provinces (territories) and derive their authority and responsibilities from the same. For a good description of the constitutional relationships that exist within Canada, see Boadway \& Watts (2000).

3 There are no separate, independent regional government structures within Canada. However, provincial governments can and do specify regional entities at the municipal level, which subsume previous independentlyoperating communities into a larger regional community.

4 For instance, there are no separate elections for Atlantic Canada, there is no legislative assembly for the region, there is no capital city for Atlantic Canada, and there are very few voices speaking for Atlantic Canada on intergovernmental issues with either the federal government or with other provincial governments.
} 
geographical basis and when tracking the distribution of national programs on a regional basis.

There are many indicators that can be employed to reflect the relative economic development status of a region, but it is not possible to consider all of these in this paper. Instead, to reflect the relative state of economic development within Atlantic Canada, this paper will consider only constant dollar or real Gross Domestic Product (GDP) per capita, the measured unemployment rate and population. ${ }^{5}$ Figure 1 illustrates that real GDP per capita in each province in Atlantic Canada has been below the average experience nationally. With the exception of Newfoundland and Labrador, which started to produce oil in 1997, the relative economic circumstances in Atlantic Canada have improved only marginally over the last 25 years. ${ }^{6}$ To provide perspective and to facilitate comparability with other jurisdictions, Table 1 reports the level of real GDP per capita for Canada and the four Atlantic provinces for 1981 and 2006. Even though there has not been a dramatic improvement in the relative performance in Atlantic Canada, there has been clearly an absolute improvement in GDP per capita in each of the Atlantic Provinces and Canada - the increase has been $113 \%$ in Newfoundland and Labrador, $71 \%$ in Prince Edward Island, 64\% in Nova Scotia, $78 \%$ in New Brunswick and 50\% in Canada.

5 Constant dollar or real GDP per capita uses chained 2002 prices and removes the impact of inflation and price changes from this indicator to reflect changes in output rather than changes in the value of output. The measured unemployment rate is the percentage of the labour force that is unemployed.

6 The relative position of Newfoundland and Labrador has improved because of the production of oil in its offshore, which has also increased in value in recent years. In fact, using nominal GDP per capita would put that province above the Canadian average in recent years. Specifically, in 2006 its nominal GDP per capita was $113 \%$ of the national average. 
FIGURE 1 - REAL GROSS DOMESTIC PRODUCT PER CAPITA (2002) IN THE ATLANTIC PROVINCES RELATIVE TO THE NATIONAL AVERAGE

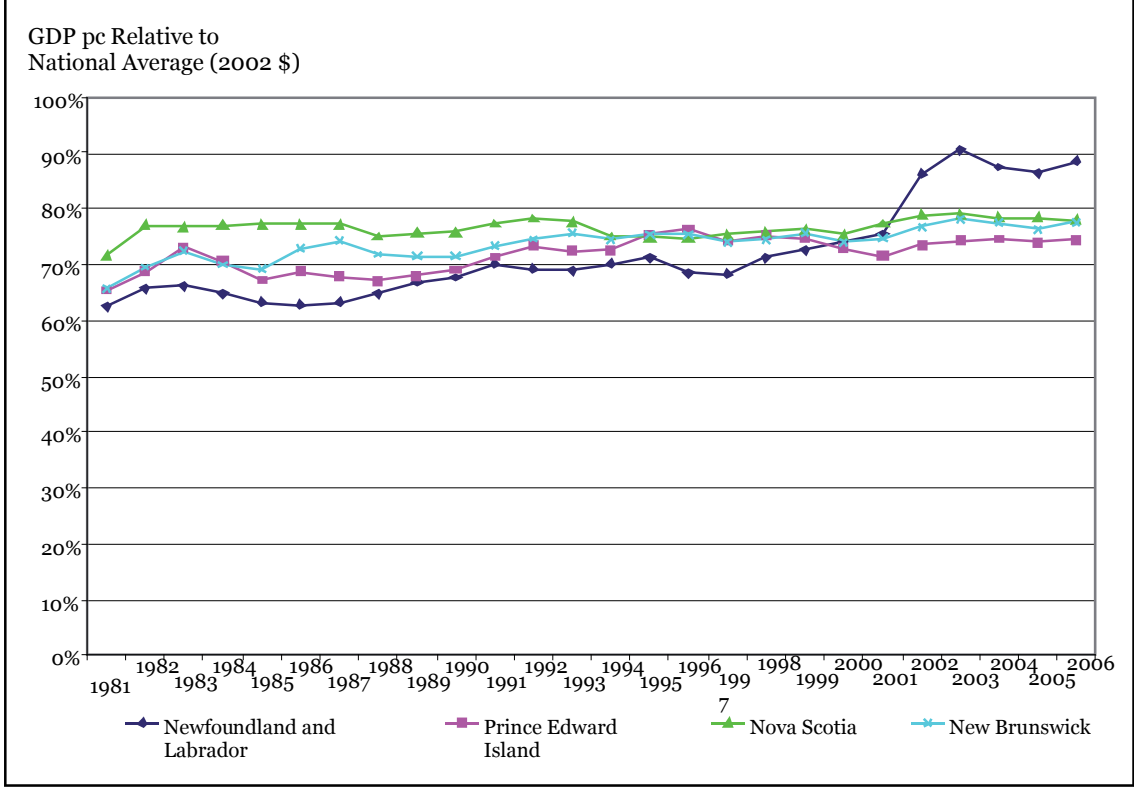

Source: Canada (2007b).

TABLE 1 - REAL GDP PER CAPITA (2002) FOR CANADA AND THE ATLANTIC PROVINCES

\begin{tabular}{lcc}
\hline & $\mathbf{1 9 8 1}$ & $\mathbf{2 0 0 6}$ \\
Canada & $\$ 26,080$ & $\$ 39,303$ \\
Newfoundland and Labrador & $\$ 16,293$ & $\$ 34,765$ \\
Prince Edward Island & $\$ 17,068$ & $\$ 29,231$ \\
Nova Scotia & $\$ 18,692$ & $\$ 30,605$ \\
New Brunswick & $\$ 17,134$ & $\$ 30,491$ \\
\hline
\end{tabular}

Source: Canada (2007b).

Another common metric used to judge regional economic development is the measured unemployment rate. From Figure 2 and Table 2, one observes that this indicator has not improved relative to the national average in either of the Atlantic Provinces. In fact, although Prince Edward Island, Nova Scotia, New Brunswick saw an improvement in their unemployment rates, Newfoundland and Labrador experienced a slightly higher unemployment rate in 2006 than existed in 1981 even though an increase in GDP that brings 
it above the Canadian average. ${ }^{7}$

FIGURE 2 - MEASURE UNEMPLOYMENT RATES IN THE ATLANTIC PROVINCES RELATIVE TO THE NATIONAL AVERAGE

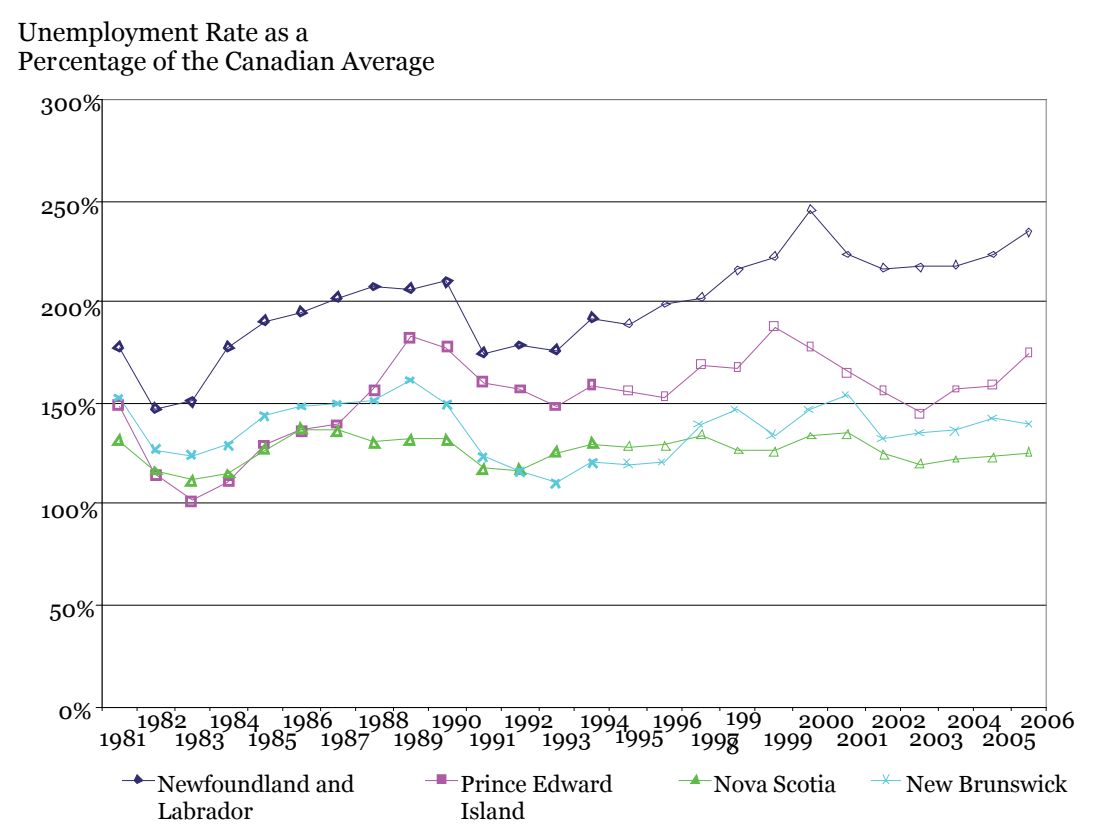

Source: Canada (2007b).

TABLE 2 - MEASURE UNEMPLOYMENT RATES IN THE ATLANTIC PROVINCES RELATIVE TO THE NATIONAL AVERAGE

\begin{tabular}{lcc}
\hline & $\mathbf{1 9 8 1}$ & $\mathbf{2 0 0 6}$ \\
Canada & $7.6 \%$ & $6.3 \%$ \\
Newfoundland and Labrador & $13.5 \%$ & $14.8 \%$ \\
Prince Edward Island & $11.3 \%$ & $11.0 \%$ \\
Nova Scotia & $10.0 \%$ & $7.9 \%$ \\
New Brunswick & $11.6 \%$ & $8.8 \%$ \\
\hline
\end{tabular}

Source: Canada (2007b). 
The final indicator, population, is profiled in Figure 3. The population of Canada has grown at a relatively constant rate from 24.8 million people in 1981 to more than 32.6 million in 2006. ${ }^{8}$ On the other hand, the population of Atlantic Canada grew initially from 2.26 million in 1981 to a peak of 2.39 million in 1993 before falling back to 2.33 million in 2006. This fall in population in recent times has been fueled by out-migration, primarily from Newfoundland and Labrador as people left to search out economic opportunities in other parts of the country.

FIGURE 3 - POPULATION IN THE ATLANTIC PROVINCES AND CANADA

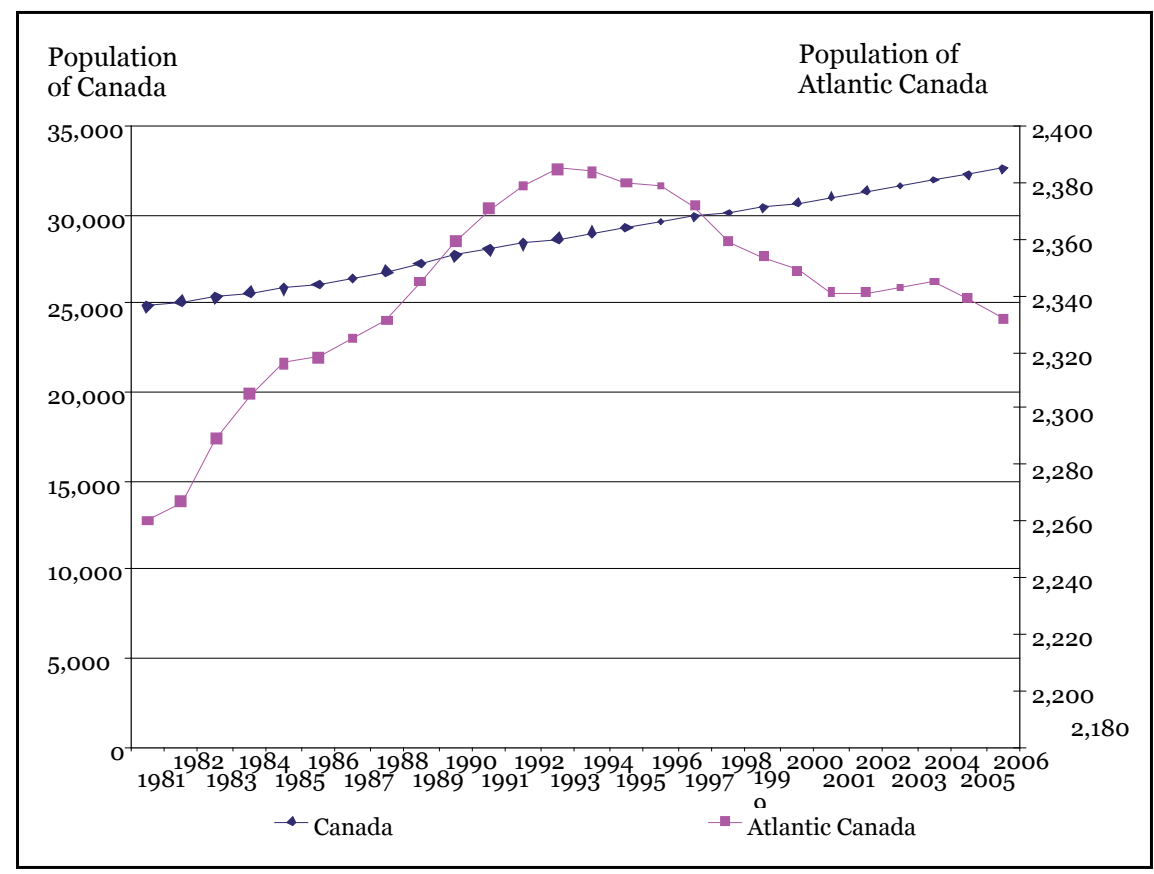

Source: Canada (2007b).

On the basis of these indicators and others not discussed here, it is clear that Atlantic Canada has regional economic development challenges to overcome relative to the rest of Canada. This is one area where the higher education sector could play an important role. 


\section{Overview of the Higher Education Sector in Atlantic \\ Canada $^{9}$}

There are four community college systems with 50 campuses and 17 universities in Atlantic Canada. There were 96,000 students enrolled in universities and 57,000 enrolled in community colleges in 2004 for a total of 153,000 full-time and part-time students (Locke et al. 2007:33). These institutions range in size from 148 students enrolled in the Atlantic School of Theology to 18,300 students enrolled at Memorial University to nearly 22,000 students enrolled in Nova Scotia's community college system.

Atlantic Canada has some of the highest university participation rates in the country. For example, Association of Universities and Colleges of Canada reports that in 2005 there were $23.9 \%$ of 18 to 21 old individuals who participated in university (Locke et al. 2007:27). The corresponding estimates for the Atlantic Provinces were: Newfoundland and Labrador $-32.0 \%$, Prince Edward Island $-30.4 \%$, Nova Scotia 33.3\% and New Brunswick - 29.6\%. As well, Atlantic Canada, as shown in Table 3, has some of the highest graduation rates within Canada. In fact, more than 18, 300 university degrees, diplomas and certificates were granted at Atlantic Canadian universities and community colleges in 2004 (Canada 2007a). This consisted of: 3,160 in Newfoundland and Labrador, 675 in Prince Edward Island, 9,560 in Nova Scotia and 4,940 in New Brunswick.

TABLE 3 - UNIVERSITY GRADUATION RATES, LEVEL OF DEGREE, 2004

\begin{tabular}{|c|c|c|c|c|c|}
\hline Degree & $\begin{array}{l}\text { Newfoundland } \\
\text { \& Labrador }\end{array}$ & $\begin{array}{l}\text { Prince } \\
\text { Edward } \\
\text { Island }\end{array}$ & $\begin{array}{l}\text { Nova } \\
\text { Scotia }\end{array}$ & $\begin{array}{c}\text { New } \\
\text { Brunswick }\end{array}$ & Canada \\
\hline $\begin{array}{l}\text { Bachelor's \& } 1^{\text {st }} \\
\text { Professional }\end{array}$ & $33 \%$ & $31 \%$ & $54 \%$ & $39 \%$ & $33 \%$ \\
\hline Masters & $7 \%$ & $2 \%$ & $14 \%$ & $5 \%$ & $7 \%$ \\
\hline Earned Doctorate & $0.6 \%$ & $0.2 \%$ & $0.7 \%$ & $0.4 \%$ & $1.0 \%$ \\
\hline
\end{tabular}

Source: Canada (2007b).

\section{How do higher education institutions contribute to economic development within Atlantic Canada?}

The first and most obvious is that higher education institutions train and educated students and in so doing transfer technology from these institutions

\footnotetext{
9 A good overview of Canada's educational system can be found at the Council of Ministers of Education, Canada's website:

http://www.educationcanada.cmec.ca/EN/EDSys/over.php.

Another excellent overview of Canada's post-secondary education system can be found at the Canadian Information Centre for International Credentials' (cicic) website:

http://www.cicic.ca/en/page.aspx?sortcode=2.12.21.
} 
to the rest of the economy through the human capital embodied in their graduating student. This could be in the form of specific vocational-type skills that are in short supply in the economy such as welders and electricians, through trained professionals such as engineers and physicians or in terms of a better educated, more flexible workforce that is better able to adapt or react to the challenges that are presented by competition in the knowledge based economy. Enhanced levels of levels of human capital augment the innovative and productive capacity of the region, creating an environment in which economic development can flourish. In terms of people attending and graduating from higher education institutions, Atlantic Canada does well relative to that experienced Canada-wide.

A second avenue through which economic impacts flow from higher education institutions to the regions is through the direct employment of people (professors, staff and students) and via the purchases of goods and services from local businesses. For some of the universities located in smaller towns throughout Atlantic Canada, it has been estimated that the institutions account for as much of $75 \%$ of income and $40 \%$ of employment in those communities. Even within the bigger cities within Atlantic Canada, universities contribute between $4 \%$ and $7 \%$ income and employment. ${ }^{10}$

As impressive as these impacts are, the contribution to economic development from higher education institutions within Atlantic Canada is more complex and more pervasive. These impacts occur as a result of collaboration and consultation between the faculty and the private sector; through directed or contract research that utilizes the institutions expertise to address local issues and problems; through targeted curriculum development and student training that meets the immediate and anticipated labour market needs of the region; through the sharing of infrastructure; and through spin-off enterprises that are either incubated within or emanate from the institution.

Furthermore, it is important to recognize the role that higher education institutions play in undertaking research and development (R\&D) within the region. For instance, Atlantic Canada's expenditures on R\&D as a percent of real GDP is below national levels, reaching $1.4 \%$ in 2005 compared to $2.2 \%$ for Canada. However, the higher education institutions play a proportionately greater role in R\&D in Atlantic Canada compared to the rest of the country, accounting for $58 \%$ of $\mathrm{R} \& \mathrm{D}$ in the region and $34 \%$ in the country in 2005. On the other hand, private sector firms conducted just over half (55\%) of R\&D performed nationally in 2005, whereas the corresponding figure in Atlantic Canada was only 26\% (Canada 2008).

While it may be stating the obvious, the contribution to economic development within the region will be more effective if local and regional engagement is seen as part of the explicit or implicit mandate of the higher education institutions. 
Within Atlantic Canada, all higher education institutions report that a local, provincial and/or regional mission is part of their mandate, mission and/or strategic direction (see Locke et al. 2007:29). Interestingly, this appears to be more voluntary rather than imposed, at least for universities. In particular, Atlantic Canadian universities indicate that being publicly-funded, there is a general expectation that local or provincial engagement would be one of the activities in which these institutions participate (Locke et al. 2007:30-1). Therefore, this increases the likelihood that the resources of the higher education institutions will be used to enhanced economic development within the region.

While the focus of research activities with Atlantic Canada's higher education institutions primarily reflects the strengths and interests of the individual researchers, these research activities draw upon the characteristics of the area in which the institutions are located. Although the research focus and policies of most institutions incorporates a regional, provincial or local focus, it may not always be identified explicitly in the institution's mission statement or through the objectives espoused in its strategic plan, but it may be reflected through the actions of the institution in promoting projects that have involvement with local industry or communities (Locke et al. 2007:47-9).

Technology transfer is another means of facilitating and enhancing local economic development. Technology transfer offices are currently established at many Atlantic Canadian universities and community colleges including all the larger institutions. In addition, a regional network to encourage technology transfer and research commercialization has recently been established. ${ }^{11}$ As well, it is necessary to acknowledge that other stakeholders have facilitated commercialization and transfer of technology within Atlantic Canada. For instance, the federal government has funded technology transfer and industry liaison offices and the national granting councils; provided scientific tax credits, innovation funding through the Atlantic Innovation Fund, and financial assistance of spin-off companies and support for incubators through the Atlantic Canada Opportunities Agency and the National Research Council. Finally, provincial governments contributed financially to strategic areas, including university research projects, equity financing for start-up companies and matching funds for federal programs.

11 This is known as Springboard and its goal is to "enhance the efficiency and effectiveness of technology transfer at all universities in Atlantic Canada and to promote and accelerate the commercialization of technologies by Atlantic Canadian companies." By providing a network of resources, Springboard is able to ensure more equal access to resources among its 14 member universities, such as specialized staff and support services, to all universities in the region including smaller institutions. Springboard's activities include: delivering educational programs relative to intellectual property; planning networking events to bring researchers and business people together; supporting the creation of new companies based on platform technologies; marketing and licensing technologies; developing and managing proof of concept projects; assessing discoveries and intellectual property opportunities; liaising with industry; and facilitating industry-sponsored research. Springboard is supported by a $\$ 3.6$ million contribution from ACOA's Atlantic Innovation Fund. 
To stimulate innovation and knowledge transfer between their researchers and industry, universities and communities colleges have (1) established industry liaison functions to assist with collaboration between researchers and industry; (2) encouraged local supporting networks and faculty collaboration; (3) provided more accommodating institutional arrangements; (4) promoted a research culture in faculties; (5) fostered administrative leadership that stimulates processes leading to strategic interactions among scholars; (6) attempted to recruit and retain of talented faculty; (7) encouraged graduate students with the interests and skills to seek out opportunities for making contributions to future research; (8) enhanced support for multidisciplinary approaches to research and collaboration; (9) facilitated industry-university linkages and the exchange of ideas and information; (10) created start-up grants for outstanding recruited faculty; (11) facilitated scholarly exchanges through workshops; and disseminated information to industry and researchers (Locke et al. 2007:67-9).

Finally, given the importance of small and medium-sized enterprises (SMEs) to the local economy and to economic development, Atlantic Canadian higher education institutions have attempted to meet the needs of local business. This has been achieved through various institutes or outreach centres within the institutions, through federal and provincial funding programs that enable university and community college researchers to address the particular problems encountered by SMEs; through explicit institutional networking and commercialization initiatives; through the technology transfer office performing a liaison function between local businesses with specific needs and their researchers with relevant expertise, and through individual researchers being approached individually by businesses. In addition, some universities meet with companies to identify their needs and how the universities may serve those needs; deliver presentations on university capabilities; develop and undertake industrial-sponsored research projects; and implement new business development activities with industry and funding partners.

\section{Atlantic Canada - Success Stories}

While it always easy to find things that ought to be done or done better, it is impressive to realize just what is being achieved in terms of the contribution of higher education institutions in Atlantic Canada to regional engagement and to economic development. While there are hundreds of examples one could cite in this regard, it is worth highlighting some selected examples of successes in local engagement that may act as examples for other jurisdictions. ${ }^{12}$

The first example is Memorial University's Leslie Harris Centre of Regional Policy and Development. This institute co-ordinates and facilitates the 
university's educational, research and outreach activities in the areas of regional policy and development. The activities of this institute have enabled the university's expertise to address some of the most important economic development issue facing the province. As a result of the interventions of this institute, the local economy has been in a better position to capitalize on economic development opportunities and to mitigate the negative consequence of development challenges faced by the province.

A second example is the Universite de Moncton's contribution to the "Acadian Miracle." This university has played a vital role in facilitating and enhancing economic development in the Acadian community within Atlantic Canada. It has allowed this cultural group within Atlantic Canada to educate its leaders and to prosper as the community effectively addresses issues that are important for its own economic development.

The third example is University of Prince Edward Island's Institute for Island Studies. Being the only island province in Canada, this institute has a mandate to encourage a deep knowledge and understanding Prince Edward Island and to serve as a bridge between the University and local communities. As well, this institute draws on the experiences of other island economies to benefit the economic development of the province.

The fourth example is the Nova Scotia Community College efforts to helping local grape growers understand micro-climates through remote sensing and weather data transmission. By providing its expertise to these local farmers, it enhanced the quality of their product and contributes to the economic development of the region.

Finally, Metropolis Atlantic is pan-Atlantic Canadian university initiative that is resident in Saint Mary's University and Université de Moncton. It is a multi-institutional initiative examining immigration issues from an Atlantic Canadian perspective. One of the characteristics of Atlantic Canada is that the population is aging and immigrants to Canada have not been settling in Atlantic Canada. This initiative attempts to understand how a potential source of immigrant can be attracted to help offset the impending labour shortages that are inevitable in Atlantic Canada with initiative such as this.

\section{Conclusion}

Atlantic Canadian higher education institutions have been successful in contributing to economic development with the region. However in order to continue these successes, it is important to continue to raise awareness of the importance and legitimacy of regional engagement. While this is true at the administrative level, it is equally relevant at the faculty and the stakeholder levels as well. Moreover, the region needs young researchers to get involved and the 
institutions need to be sensitive to how they interact with other stakeholders in that higher education institution are not always easy to approach.

In addition, the there needs to be a coordinated plan of action for regional engagement to enhance local economic development within the region. This would include a provincial grant programs to stimulate local research and contribute to absorptive capacity of the region and would include regional engaged activities explicitly in promotion and tenure decisions undertaken at the higher education institutions within the region.

Finally, there are many examples of successful contribution of the higher education institutions to economic development in Atlantic Canada. These could offer positive illustrations that might prove useful to other jurisdictions that are concerned with enhancing the role of higher education institutions in economic development. As well, there are numerous lessons that Atlantic Canada can learn from other jurisdictions throughout the world and it is important to monitor and learn from what is happening elsewhere.

\section{References}

BOADWAY, R.; WATTS, R. (2000). Fiscal Federalism in Canada. Institute of Intergovernmental Relations, Queen's University, Kingston.

GARDNER PINFOLD CONSULTING ECONOMISTS LTD. (2006). "The Economic Impact of Universities in the Atlantic Provinces." Report prepared for The Association of Atlantic Universities, Halifax.

LOCKE, W.; BEALE, E.; GREENWOOD, R.; FARRELL, C.; TOMBLIN, S.; DEJARDINS, P.; STRAIN, F.; BALDACHINNO, G. (2007). Self Evaluation Report: Atlantic Canada, Canada. OECD-IMHE Project: Supporting the Contribution of Higher Education Institutions to Regional Development. URL: www.oecd.org/document/35/o,3343,en_2649_35961291_35602979_ 1_1_1_1,oo.html\#13.

CANADA (2007a). Education Indicators in Canada: Report of the Pan-Canadian Education Indicators Program. Statistics Canada \& Council of Ministers of Education, Catalogue 81-582-X1E, Ottawa.

CANADA (2007b). Provincial Economic Accounts. Statistics Canada \& Council of Ministers of Education, CD ROM, Ottawa.

CANADA (2008). Gross Domestic Expenditures on research and Development in Canada and the Provinces. Statistics Canada \& Council of Ministers of Education, Catalogue no. 88-221-X, Ottawa.

Submissão: 27 de março 2008.

Primeira resposta: 28 de abril de 2008.

Aceite: 20 de fevereiro de 2009 . 
